\title{
Serum $\alpha$-synuclein and IL-1 $\beta$ are increased and correlated with measures of disease severity in children with epilepsy: potential prognostic biomarkers?
}

Jieun Choi ${ }^{1 *}$ D, Soo Yeon Kim², Hunmin Kim³ , Byung Chan Lim², Hee Hwang ${ }^{3}$, Jong Hee Chae ${ }^{2}$, Ki Joong Kim², Sohee $\mathrm{Oh}^{4}$, Eun Young $\mathrm{Kim}^{1}$ and Jeon-Soo $\mathrm{Shin}^{5^{*}}$ (i)

\begin{abstract}
Background: The search for noninvasive biomarkers of neuroinflammation and neurodegeneration has focused on various neurological disorders, including epilepsy. We sought to determine whether a-synuclein and cytokines are correlated with the degree of neuroinflammation and/or neurodegeneration in children with epilepsy and with acquired demyelinating disorders of the central nervous system (CNS), as a prototype of autoimmune neuroinflammatory disorders.

Methods: We analyzed serum and exosome levels of a-synuclein and serum proinflammatory and antiinflammatory cytokines among 115 children with epilepsy and 10 acquired demyelinating disorders of the CNS and compared to 146 controls. Patients were enrolled prospectively and blood was obtained from patients within $48 \mathrm{~h}$ after acute afebrile seizure attacks or relapse of neurological symptoms. Acquired demyelinating disorders of the CNS include acute disseminated encephalomyelitis, multiple sclerosis, neuromyelitis optica spectrum disorders, and transverse myelitis. The controls were healthy age-matched children. The serum exosomes were extracted with ExoQuick exosome precipitation solution. Serum $\alpha$-synuclein levels and serum levels of cytokines including IFN- $\beta$, IFN- $\gamma$, IL-1 $\beta, I L-6, I L-10$ and TNF-a were measured using single and multiplex ELISA kits. Data were analyzed and compared with measures of disease severity, such as age at disease onset, duration of disease, and numbers of antiepileptic drug in use.

(Continued on next page)
\end{abstract}

\footnotetext{
* Correspondence: jechoi66@snu.ac.kr; jieunchoi6647@hanmail.net; jsshin6203@yuhs.ac

'Department of Pediatrics, Seoul National University College of Medicine,

Seoul Metropolitan Government Seoul National University Boramae Medical

Center, Boramaero 5 gil 20, Dongjakgu, Seoul 07061, South Korea

${ }^{5}$ Department of Microbiology, Brain Korea 21 Plus Project for Medical

Science, Severance Biomedical Science Institute and Institute for

Immunology and Immunological Diseases, Yonsei University College of

Medicine, 50-1 Yonsei-ro Seodaemoon-gu Seoul, Seoul 03722, South Korea

Full list of author information is available at the end of the article
}

(c) The Author(s). 2020 Open Access This article is licensed under a Creative Commons Attribution 4.0 International License, which permits use, sharing, adaptation, distribution and reproduction in any medium or format, as long as you give appropriate credit to the original author(s) and the source, provide a link to the Creative Commons licence, and indicate if changes were made. The images or other third party material in this article are included in the article's Creative Commons licence, unless indicated otherwise in a credit line to the material. If material is not included in the article's Creative Commons licence and your intended use is not permitted by statutory regulation or exceeds the permitted use, you will need to obtain permission directly from the copyright holder. To view a copy of this licence, visit http://creativecommons.org/licenses/by/4.0/. The Creative Commons Public Domain Dedication waiver (http://creativecommons.org/publicdomain/zero/1.0/) applies to the data made available in this article, unless otherwise stated in a credit line to the data. 


\begin{abstract}
(Continued from previous page)
Results: Serum a-synuclein levels were significantly increased in patients with epilepsy and acquired demyelinating disorders of the CNS compared to controls (both, $p<0.05$ ) and showed correlation with measures of disease severity both in epilepsy $(p<0.05, r=0.2132)$ and in acquired demyelinating disorders of the CNS $(p<0.05, r=$ $0.5892)$. Exosome $a$-synuclein showed a significant correlation with serum $a$-synuclein $(p<0.0001, r=0.5915)$. Serum IL-1 $\beta$ levels were correlated only with the numbers of antiepileptic drug used in children with epilepsy $(p<0.001$, $r=0.3428$ ), suggesting drug resistant epilepsy.

Conclusions: This is the first study in children demonstrating that serum a-synuclein levels were significantly increased in children with epilepsy and with acquired demyelinating disorders of the CNS and correlated with measures of disease severity. Serum IL-1 $\beta$ levels showed significant correlation only with drug resistance in children with epilepsy. Thus, these data support that serum levels of a-synuclein and IL-1 $\beta$ are potential prognostic biomarkers for disease severity in children with epilepsy. CNS, central nervous system.
\end{abstract}

Keywords: a-Synuclein, IL-1ß, Epilepsy, Children, Acquired demyelinating disorders,

\section{Background}

Pediatric epilepsy is a chronic brain disorder accompanied by behavioral and cognitive problems, which include intellectual dysfunctions and attention deficits. The International League Against Epilepsy (ILAE) defines epilepsy as a condition in which a patient has "two or more unprovoked seizure attacks occurring at least 1 day apart" [1]. Approximately one-third of patients with epilepsy have drug resistant epilepsy, defined as epilepsy that is not controlled by two antiepileptic medications to sustain seizure freedom [2]. Some children with drug resistant epilepsy may show regression in intellectual abilities over time [3]. The causes of regression may include the etiology of the underlying epilepsy, the spike discharges on electroencephalogram (EEG) outputs, the seizures themselves and a variety of medications $[4,5]$, but there is no known biomarker for disease severity or neurocognitive comorbidity.

$\alpha$-Synuclein is one of the most abundant proteins within the neurons of the brain [6-8]. This protein is suggested to participate in synaptic transmission by regulating neurotransmitter release and vesicle recycling, also in mitochondrial and synaptic dysfunction and neuronal apoptosis and in $\mathrm{Ca}^{2+}$ homeostasis $[9,10]$. Oligomeric forms of $\alpha-$ synuclein have been demonstrated to increase synaptic transmission and to decrease long-term potentiation and certain oligomeric forms were reported to play a key role in the neurodegenerative process [11]. Intracellular deposition of $\alpha$-synuclein were found in several neurodegenerative diseases presenting with cognitive problems and dementia [12].

$\alpha$-Synuclein levels have been investigated in patients with various neurological disorders. Soluble oligomeric $\alpha-$ synuclein has been suggested as a potential biomarker for Parkinson's disease because of its increased plasma levels in patients [13]. Exosome $\alpha$-synuclein is mostly specific to the CNS and is found increased in patients with Parkinson's disease [14]. Cerebrospinal fluid (CSF) $\alpha$-synuclein levels are reported to be elevated in patients with multiple sclerosis and neuromyelitis optica during relapse [15] as well as in traumatic brain injury [16]. Multiple sclerosis and neuromyelitis optica are the main autoimmune inflammatory demyelinating disorders of the CNS during childhood. Chronic autoimmune neuroinflammation is the most important component of the pathology of these diseases and the progressive clinical disability, such as motor dysfunction and cognitive declines [17].

Clinical evidences have shown that neuroinflammation is a hallmark of the epileptic focus in drug-resistant epilepsy $[18,19]$. Neuroinflammatory mechanisms contribute to seizure generation in animal models of epilepsy [19]. Substantial effort has been invested in the search for noninvasive biomarkers of neuroinflammation; this search has focused on various neurological disorders including autoimmune neurological diseases, neurocognitive neurodegenerative diseases and neuropsychiatric dysfunction as well as epilepsy [20]. CSF/serum IL-1 $\beta$ levels have been reported as a prognostic factor for epilepsy development after traumatic brain injury [21], and the brain-specific adhesion molecule ICAM5 can be used to discriminate between drug-responsive and drug-resistant epilepsy [22]. In medial temporal lobe epilepsy, $\alpha$-synuclein deposition has been found in the hippocampus along with neuronal cell loss and reactive gliosis [23]. Adult patients with intractable epilepsy showed elevated $\alpha$-synuclein levels in both CSF and serum [24]. However, there are no reports about $\alpha$-synuclein levels in children with epilepsy, who usually have earlier disease onset and are more likely to develop intellectual disability and behavioral problems.

We aimed to determine whether serum and exosomal levels of $\alpha$-synuclein and cytokines are correlated with degrees of neuroinflammation and neurodegeneration in children with epilepsy and a prototypical class of neuroinflammatory disorders, namely, acquired demyelinating disorders of the CNS. For this purpose, we analyzed serum and exosomal levels of $\alpha$-synuclein and serum 
proinflammatory and anti-inflammatory cytokines among children with epilepsy and acquired demyelinating disorders of the CNS and compared to controls.

\section{Methods}

\section{Patient information}

We prospectively enrolled 115 epilepsy patients having afebrile seizure attacks within the last $48 \mathrm{~h}$ before visiting the pediatric neurology clinic of Seoul National University Boramae Medical Center. Epilepsy was diagnosed and classified according to the criteria established in the 2017 International Classification of Epileptic Syndromes [25]. Children with epilepsy underwent examinations that included medical history, physical and neurological examinations, electroencephalograms, blood tests (including metabolic and autoimmune studies) and brain magnetic resonance imaging (MRI). Autoimmune epilepsy, neonatal seizures, infantile spasms, posttraumatic epilepsy and post-encephalitic epilepsy were excluded. Ten patients with acquired demyelinating disorders of the CNS were included and diagnosed according to the revised definitions proposed by the International Pediatric Multiple Sclerosis Study Group [26]. Acquired demyelinating disorders of the CNS include acute disseminated encephalomyelitis (ADEM), multiple sclerosis (MS), neuromyelitis optica spectrum disorder (NMOSD), and transverse myelitis (TM) [26]. MS were diagnosed based on the criteria proposed in 2010 by McDonald [27] and NMOSD were diagnosed based on the 2015 Wingerchuk diagnostic criteria [28]. TM were diagnosed based on the 2013 International Pediatric Multiple Sclerosis Study Group criteria for TM [26]. Among ADEM, MS, NMO and TM, blood tests were performed two to five times in a patient at the time of relapse or worsening of symptoms to measure differences from the initial attack and relapse; each test was counted as separate and compared serially with the disease duration. So, total numbers of tests were 18 times, and we analyzed each tests individually. For correlation analysis of serum $\alpha$-synuclein and cytokine levels with measures of disease severity, we quantified disease severity using the age of disease onset, the duration of disease, the duration of the last seizure before the blood collection and the number of antiepileptic medications in patients with epilepsy and the age of disease onset and the duration of disease in patients with acquired demyelinating disorders of the CNS. The 146 controls were healthy age-matched children who visited headache clinics for routine workup but did not have acute current headache attacks or any history of febrile seizures, epilepsy, or acquired demyelinating disorders of the CNS. This study was approved by the Institutional Review Board at the Seoul National University Boramae Medical Center. Informed written consent was obtained from the parent of each child, and verbal assent was obtained from each child or adolescent.

\section{Serum and exosome purification}

Blood was obtained from patients within $48 \mathrm{~h}$ after acute seizure attacks or relapse of neurologic symptoms such as visual loss or sudden motor deficits. Serum was separated and frozen for subsequent cytokine and $\alpha$-synuclein assays. Control blood serum was collected and frozen as above.

The serum exosomes were extracted with ExoQuick exosome precipitation solution (System Biosciences, CA, USA) [29]. Briefly, the serum was centrifuged at $3000 \mathrm{~g}$ at $4{ }^{\circ} \mathrm{C}$ for $15 \mathrm{~min}$. Then, the supernatant and one-fourth of its volume in ExoQuick Solution were mixed well and incubated at $4{ }^{\circ} \mathrm{C}$. After $2 \mathrm{~h}$, the mixture was centrifuged for $30 \mathrm{~min}$ at $1500 \mathrm{~g}$, after which the pellet was dissolved and re-centrifuged for $5 \mathrm{~min}$ at $4{ }^{\circ} \mathrm{C}$. The exosome-containing pellet was re-suspended in nuclease-free water.

\section{a-Synuclein and cytokine measurement}

Serum $\alpha$-synuclein levels were measured using commercially available enzyme-linked immunosorbent assay (ELISA) kits (Thermo Scientific, Waltham, MA [24]). Serum levels of cytokines including interferon (IFN)- $\beta$, IFN- $\gamma$, interleukin (IL)-1 $\beta$, IL-6, IL-10 and tumor necrosis factor (TNF)- $\alpha$ were measured using commercially available multiplex kits (Merck, Darmstadt, Germany) according to the manufacturer's instructions. Samples were analyzed in duplicate and compared with controls. The lower limits of detection were $0.2 \mathrm{ng} / \mathrm{mL}$ for $\alpha$-synuclein, $115.1 \mathrm{pg} / \mathrm{ml}$ for IFN- $\beta, 0.8 \mathrm{pg} / \mathrm{ml} \mathrm{IFN-} \gamma, 0.8 \mathrm{pg} / \mathrm{mL}$ for IL- $1 \beta, 0.9 \mathrm{pg} / \mathrm{mL}$ for IL-6, $1.1 \mathrm{pg} / \mathrm{mL}$ for IL-10 and $0.7 \mathrm{pg} / \mathrm{mL}$ for TNF- $\alpha$.

\section{Statistical analysis}

The data are presented as the mean \pm 1 standard deviation (SD) ( $\alpha$-synuclein and cytokine levels). The MannWhitney test was used to compare the serum levels of $\alpha$ synuclein and cytokines in patients with epilepsy and acute demyelinating disorders of the CNS versus controls. The Kruskal-Wallis test was used to compare serum or exosomal levels of $\alpha$-synuclein between all patients and controls. Spearman's rank correlation coefficient was calculated to detect significant correlations of $\alpha$-synuclein levels and other cytokines or clinical variables with disease severity in the patient groups. GraphPad Prism v. 7.0 for Windows version 7.03 (GraphPad Software Inc., San Diego, CA, USA) was used to perform the above tests. Values are expressed as the means, and the threshold for statistical significance was set as $p<0.05$ for all tests.

\section{Results}

\section{Patient characteristics}

The demographic and clinical features of the patients are shown in Table 1. One hundreds fifteen epilepsy patients, 10 patients with acquired demyelinating disorders of the CNS and 146 control children were included in this study. Numbers of tests done in children with acquired demyelinating 
Table 1 Demographic characteristics of the patients

\begin{tabular}{|c|c|c|c|}
\hline & Control & Epilepsy & $\begin{array}{l}\text { Acquired } \\
\text { demyelinating } \\
\text { disorders of } \\
\text { the CNS }\end{array}$ \\
\hline Number of subjects & 146 & 115 & 10 \\
\hline Number of tests & 146 & 115 & 18 \\
\hline Male/Female & $76 / 68$ & $68 / 47$ & $3 / 7$ \\
\hline $\begin{array}{l}\text { Age at test (years; } \\
\text { mean } \pm S D \text { ) }\end{array}$ & $9.4 \pm 2.9$ & $8.9 \pm 6.2$ & $8.1 \pm 4.3$ \\
\hline $\begin{array}{l}\text { Age at 1st } \\
\text { symptom onset } \\
\text { (years; mean } \pm S D \text { ) }\end{array}$ & NA & $5.8 \pm 5.2$ & $6.1 \pm 4.0$ \\
\hline $\begin{array}{l}\text { Duration of disease } \\
\text { (year; mean } \pm S D \text { ) }\end{array}$ & NA & $3.1 \pm 4.5$ & $2.1 \pm 2.9$ \\
\hline
\end{tabular}

CNS, central nervous system; SD, standard deviation; Inflammatory brain diseases include acute cerebellar ataxia, acute disseminated encephalomyelitis, multiple sclerosis, neuromyelitis optica spectrum disorder $(N=8)$ and transverse myelitis disorders of the CNS were counted as 18 because several tests were done in same patients during relapse of neurological symptoms. Then mean age at time of tests were 8.9 years old in patients with epilepsy and 8.1 years old in patients with acquired demyelinating disorders of the CNS. The mean age at the time of tests were 9.4 years old in controls and showed no significant statistical differences. Mean duration of diseases were 3.1 years in epilepsy and 2.1 years in acquired demyelinating disorders of the CNS. Types and etiologies in the epilepsy patients are shown in Table 2. Etiologies of epilepsy were 3\% structural, $10 \%$ genetic and $87 \%$ unknown. Duration of epilepsy were less than 1 year in 55\% of patients, and $34 \%$ of patients had more than 3 years. The mean duration of the last seizure before the blood collection were $8.2 \mathrm{~min}$ and $72 \%$ were less than $5 \mathrm{~min} .60 \%$ of patients had been controlled epilepsy under 1 anti-epileptic medications but $25 \%$ of patients had taken more than 3 antiepileptic medications to control seizures. Patients with acquired demyelinating disorders of the CNS include 2 with ADEM, 1 with relapsing-remitting MS, 3 with NMO and 2 with TM (Table 3). One MS, 2 NMO and 1 TM patient were tested two to five times when their neurological

Table 2 Characteristics of children with epilepsy

\begin{tabular}{|c|c|c|c|}
\hline Epilepsy syndromes & $\%(N)$ & Duration of epilepsy (years) & $\%(\mathrm{~N})$ \\
\hline Benign epilepsy with centrotemporal spikes & $16(18)$ & $<1$ & $55(63)$ \\
\hline Benign infantile epilepsy & $2(3)$ & $1 \sim 3$ & $13(15)$ \\
\hline Early myoclonic encephalopathy & $1(1)$ & $3 \sim 5$ & $8(9)$ \\
\hline Late onset childhood occipital epilepsy & $2(3)$ & $\geq 5$ & $24(28)$ \\
\hline Temporal lobe epilepsy & $11(12)$ & & \\
\hline Panayiotopoulos syndrome & $4(4)$ & & \\
\hline Generalized epilepsy with febrile seizure plus & $7(8)$ & Age at seizure onset (years) & $\%(\mathrm{~N})$ \\
\hline Childhood absence epilepsy & $7(8)$ & $<1$ & $34(39)$ \\
\hline Juvenile myoclonic epilepsy & $5(6)$ & $1 \sim 3$ & $17(19)$ \\
\hline Lennox Gastaut syndrome & $24(28)$ & $3 \sim 5$ & $10(12)$ \\
\hline Idiopathic generalized epilepsy & $16(18)$ & $5 \sim 7$ & $12(14)$ \\
\hline Symptomatic generalized epilepsy & $5(6)$ & $\geq 7$ & $27(31)$ \\
\hline Epilepsy etiology & $\%(N)$ & Duration of last seizure before blood collection (minutes) & $\%(N)$ \\
\hline Structural & $3(4)$ & $<5$ & $83(72)$ \\
\hline Genetic & $10(11)$ & $5 \sim 10$ & $11(10)$ \\
\hline Dravet syndrome & 5 & $10 \sim 30$ & $7(6)$ \\
\hline Lafora diseases & 3 & $\geq 30$ & $14(12)$ \\
\hline Rett syndrome & 2 & & \\
\hline Infectious & 0 & & \\
\hline Immune & 0 & & \\
\hline Neurodevelopmental comorbidities & $\%(\mathrm{~N})$ & Number of antiepileptic drugs (N) & $\%(\mathrm{~N})$ \\
\hline ADHD & $18(16)$ & 1 & $60(70)$ \\
\hline Autism spectrum disorder & $4(3)$ & 2 & $15(17)$ \\
\hline Mental retardation & $31(27)$ & $\geq 3$ & $25(28)$ \\
\hline
\end{tabular}

$\mathrm{N}$, number; $\mathrm{ADHD}$, attention deficit hyperactivity disorder 
Table 3 Characteristics of acquired demyelinating disorders of the central nervous system in children

\begin{tabular}{|c|c|c|c|c|c|c|c|}
\hline Diagnosis & $\begin{array}{l}\text { Age at test } \\
\text { (years; mean } \pm \\
\text { SD) }\end{array}$ & $\begin{array}{l}\text { Serum a-synuclein } \\
(\mathrm{ng} / \mathrm{ml})(\text { mean } \pm \mathrm{SD})\end{array}$ & $\begin{array}{l}\text { Patient } \\
\text { ID }\end{array}$ & $\begin{array}{l}\text { Number } \\
\text { of tests }\end{array}$ & $\begin{array}{l}\text { Number } \\
\text { of } \\
\text { relapses }\end{array}$ & Medications & Outcome \\
\hline \multirow{2}{*}{$\begin{array}{l}\text { Acute disseminated } \\
\text { encephalomyelitis }\end{array}$} & \multirow[t]{2}{*}{$7.9 \pm 1.8$} & \multirow[t]{2}{*}{$9.5 \pm 1.9$} & A & 1 & None & $I V I G, P D$ & Completely recovered \\
\hline & & & B & 1 & None & $I V I G, P D$ & Completely recovered \\
\hline Multiple sclerosis & $13.9 \pm 0.1$ & $11.0 \pm 7.4$ & C & 3 times & 3 times & $\begin{array}{l}\text { IVIG+PD+ } \\
\text { interferon- } \beta\end{array}$ & Relapsing-remitting type \\
\hline \multirow[t]{3}{*}{$\begin{array}{l}\text { Neuromyelitis } \\
\text { optica spectrum } \\
\text { disorder }\end{array}$} & \multirow[t]{3}{*}{$8.7 \pm 3.6$} & \multirow[t]{3}{*}{$13.7 \pm 4.8$} & D & 1 & 2 times & $\begin{array}{l}\text { IVIG+PD+ } \\
\text { AZP }+ \\
\text { plasmapheresis }\end{array}$ & Expired \\
\hline & & & $E$ & 2 times & 3 times & IVIG+PD+ AZP & $\begin{array}{l}\text { Rapid disease progression; bedridden } \\
\text { with home ventilator }\end{array}$ \\
\hline & & & $\mathrm{F}$ & 5 times & 4 times & IVIG+PD+ AZP & $\begin{array}{l}\text { Slow disease progression, but can } \\
\text { walk independently }\end{array}$ \\
\hline \multirow[t]{3}{*}{ Transverse myelitis } & \multirow[t]{3}{*}{$3.8 \pm 1.8$} & \multirow[t]{3}{*}{$10.8 \pm 7.9$} & G & 1 & None & $\mathrm{IVIG+PD}$ & Rapidly and completely recovered \\
\hline & & & $\mathrm{H}$ & 1 & None & $I V I G+P D$ & Rapidly and completely recovered \\
\hline & & & । & 3 times & None & IVIG+PD & $\begin{array}{l}\text { Unresponsive to treatment for the } \\
\text { first two months, but slowly } \\
\text { recovered }\end{array}$ \\
\hline
\end{tabular}

SD; standard deviation, ID; identification, IVIG, intravenous immunoglobulin; PD; prednisolone, AZP; azathioprine

symptoms were aggravated or relapsing; therefore, the total number of tests was counted as 18 (Table 1 and Table 3). Repeated tests were performed in one MS (3 times), 2 NMOSD (2 times and 5 times) and 1 TM (3 times) at the time of relapse or worsening of symptoms (Table 3 ).

\section{Serum a-synuclein was significantly increased in patients with epilepsy and acquired demyelinating disorders of the CNS and was correlated with measures of disease severity} Serum $\alpha$-synuclein levels were significantly increased in patients with epilepsy and acquired demyelinating disorders of the CNS compared to controls (Tables 4, 9.5 and 11.2 vs $8.0 \mathrm{ng} / \mathrm{ml}$, both $p<0.05)$. Serum $\alpha$-synuclein levels were significantly different in patients with epilepsy and acquired demyelinating disorders of the CNS compared to controls, in three group comparisons (Fig. 1 (A), $p<0.05)$. In the subgroup of acquired demyelinating disorders of the CNS, serum $\alpha$-synuclein was 13.7 $\mathrm{ng} / \mathrm{ml}$ in $\mathrm{NMO}, 11.0 \mathrm{ng} / \mathrm{ml}$ in $\mathrm{MS}, 10.8 \mathrm{ng} / \mathrm{ml}$ in $\mathrm{TM}$ and $9.5 \mathrm{ng} / \mathrm{ml}$ in ADEM compared to $8.0 \mathrm{ng} / \mathrm{ml}$ in controls (Table 3).

Correlation analysis between serum $\alpha$-synuclein and disease severity revealed that the number of antiepileptic medications and the duration of last seizure before the blood collection were correlated with serum $\alpha$-synuclein and IL- 6 levels in patients with epilepsy (Table 5 and Fig. 1 (B) \& 3 (C); $p<0.05, r=0.2132$ and $p<0.05, r=$ 0.1884 ). In patients with acquired demyelinating disorders of the CNS, the duration of diseases was positively correlated with serum $\alpha$-synuclein levels (Table 5 and Fig. 1 (C), $p<0.05, r=0.5892$ ). However, the age of disease onset did not correlate with serum $\alpha$-synuclein levels in patients with epilepsy (Table $5, p=0.6352$ ) or with acquired demyelinating disorders of the CNS (Table 5, $p=0.4864$ ).

Serum $\alpha$-synuclein did not showed significant correlation with serum levels of IFN- $\beta$, IFN- $\gamma$, IL-1 $\beta$, IL-6, IL10 and TNF- $\alpha$ in patients with epilepsy and acquired demyelinating disorders of the CNS.

Table 4 Comparisons of serum a-synuclein and cytokines between epilepsy, acquired demyelinating disorders of CNS and controls

\begin{tabular}{llllll}
\hline Serum levels & Control $(\mathrm{N}=146)$ & Epilepsy $(\mathrm{N}=115)$ & $p$-value & Acquired demyelinating ds $(\mathrm{N}=18)$ & $p$-value \\
\hline a-Synuclein $(\mathrm{ng} / \mathrm{ml})$ & $8.0 \pm 4.3$ & $9.5 \pm 5.0$ & $0.0160^{*}$ & $11.2 \pm .5 .9$ & $0.0250^{*}$ \\
IFN- $\beta(\mathrm{pg} / \mathrm{ml})$ & $397.5 \pm 312.3$ & $475.5 \pm 333.8$ & 0.0646 & $814.9 \pm 1227.3$ & 0.4672 \\
$\mathrm{IFN}-\boldsymbol{\gamma}(\mathrm{pg} / \mathrm{ml})$ & $3.5 \pm 9.3$ & $4.6 \pm 13.1$ & 0.1718 & $6.1 \pm 18.5$ & 0.5644 \\
$\mathrm{IL}-1 \beta(\mathrm{pg} / \mathrm{ml})$ & $0.5 \pm 1.0$ & $3.5 \pm 13.9$ & 0.1038 & $0.4 \pm 0.7$ & 0.3141 \\
$\mathrm{IL}-6(\mathrm{pg} / \mathrm{ml})$ & $0.9 \pm 1.4$ & $4.2 \pm 11.8$ & $0.0052^{*}$ & $7.0 \pm 15.5$ & 0.1833 \\
IL-10 $(\mathrm{pg} / \mathrm{ml})$ & $4.0 \pm 9.9$ & $9.2 \pm 20.9$ & $<0.0001^{* *}$ & $17.7 \pm 34.9$ & $0.0120^{*}$ \\
TNF- $-\mathrm{pg} / \mathrm{ml})$ & $10.2 \pm 6.3$ & $14.3 \pm 14.8$ & $0.0475^{*}$ & $12.1 \pm 11.6$ & 0.3959 \\
\hline
\end{tabular}

Data, mean \pm standard deviation; CNS, central nervous system; Acquired demyelinating ds, acquired demyelinating disorders of the central nervous system; IFN, interferon; IL, interleukin; TNF, tumor necrosis factor; ${ }^{*} p<0.05,{ }^{* *} p<0.001$ 
Table 5 Correlations of serum a-synuclein and cytokines with measures of disease severity in epilepsy and acquired demyelinating disorders of CNS

\begin{tabular}{|c|c|c|c|c|c|c|c|c|c|c|c|c|}
\hline \multirow[t]{3}{*}{ Serum levels } & \multicolumn{8}{|c|}{ Epilepsy ( $N=115)$} & \multicolumn{4}{|c|}{ Acquired demyelinating ds $(\mathrm{N}=18)$} \\
\hline & \multicolumn{2}{|c|}{$\begin{array}{l}\text { Age of disease } \\
\text { onset }\end{array}$} & \multicolumn{2}{|c|}{$\begin{array}{l}\text { Duration of last sz before } \\
\text { the blood collection }\end{array}$} & \multicolumn{2}{|c|}{ Number of AED } & \multicolumn{2}{|l|}{$\begin{array}{l}\text { Disease } \\
\text { duration }\end{array}$} & \multicolumn{2}{|c|}{$\begin{array}{l}\text { Age of disease } \\
\text { onset }\end{array}$} & \multicolumn{2}{|l|}{$\begin{array}{l}\text { Disease } \\
\text { duration }\end{array}$} \\
\hline & $p$-value & $r$ & $p$-value & $r$ & $p$-value & r & $p$-value & $r$ & $p$-value & $r$ & $p$-value & $r$ \\
\hline a-Synuclein (ng/ml) & 0.6352 & & $0.0438^{*}$ & 0.1884 & $0.0222^{*}$ & 0.2132 & 0.5575 & & 0.4864 & & $0.0374^{*}$ & 0.5892 \\
\hline IFN- $\beta$ (pg/ml) & 0.6274 & & 0.8148 & & 0.6119 & & 0.6568 & & 0.2188 & & 0.3941 & \\
\hline IFN- $\gamma(p g / m l)$ & $<0.0001^{* *}$ & -0.4197 & 0.4590 & & $0.0235^{*}$ & 0.2288 & 0.0872 & & 0.8242 & & 0.6411 & \\
\hline $\mathrm{IL}-1 \beta(\mathrm{pg} / \mathrm{ml})$ & $0.0110^{*}$ & -0.2545 & 0.4913 & & $0.0005^{* *}$ & 0.3428 & 0.1359 & & 0.8999 & & 0.8044 & \\
\hline IL-6 (pg/ml) & $0.0066^{*}$ & -0.2714 & $0.0057^{*}$ & 0.2773 & 0.7776 & & 0.3343 & & $0.0429^{*}$ & -0.6272 & 0.3101 & \\
\hline IL-10 (pg/ml) & $0.0041^{*}$ & -0.2864 & 0.6248 & & 0.3572 & & 0.7683 & & 0.2273 & & 0.4465 & \\
\hline TNF-a (pg/ml) & 0.4018 & & 0.7054 & & 0.2542 & & 0.6594 & & 0.3781 & & 0.3813 & \\
\hline Exosomal a-synuclein (ng/ml) & 0.1042 & & 0.1136 & & 0.3488 & & 0.2914 & & 0.5298 & & 0.0571 & \\
\hline
\end{tabular}

CNS, central nervous system; Acquired demyelinating ds, acquired demyelinating disorders of the central nervous system; sz, seizure; AED, antiepileptic drugs; IFN, interferon; IL, interleukin; TNF, tumor necrosis factor; ${ }^{*} p<0.05,{ }^{* *} p<0.001$

Exosomal a-synuclein correlated with serum a-synuclein and serum IL-6 levels in patients with epilepsy and acquired demyelinating disorders of the CNS

Exosomal $\alpha$-synuclein levels are increased in patients with epilepsy and acquired demyelinating disorders of the CNS compared with controls, although the difference was not statistically significant (Fig. 1 (D), $p=0.2341$ ). Exosomal $\alpha$ - synuclein levels were higher in epilepsy and acquired demyelinating disorders of the CNS compared to controls (1.4 and $1.1 \mathrm{vs} 0.8 \mathrm{ng} / \mathrm{ml}, p=0.3828$ and $p=0.1168$ ), although neither difference was statistically significant. Exosomal levels of $\alpha$-synuclein showed a significant correlation with serum levels of $\alpha$-synuclein in patients with epilepsy and acquired demyelinating disorders of the CNS (Fig. 1 (E), $p<$

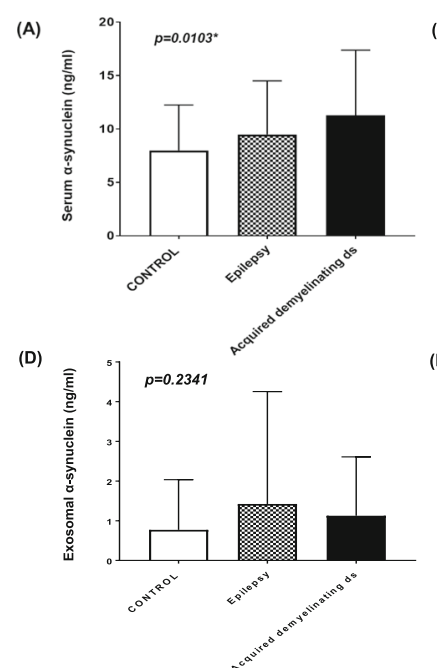

(B)

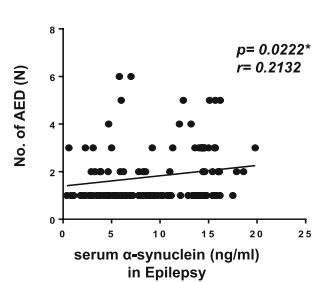

(E)

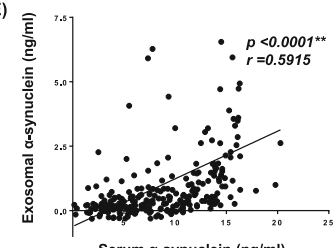

Serum $\alpha$-synuclein $(\mathrm{ng} / \mathrm{ml})$
(C)

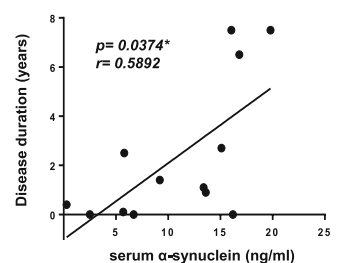

(F)

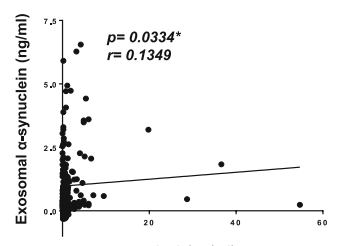

serum IL-6 (pg/ml)

Fig. 1 Correlation of serum and exosome a-synuclein with measures of disease severity in epilepsy and acquired demyelinating disorders of CNS. (a-b) Mean a-synuclein levels from serum (a) and exosomal extracts (b) in patients with epilepsy $(N=115)$, acquired demyelinating disorders of the central nervous system $(N=18)$ and controls $(N=146)$. Acquired demyelinating disorders of the central nervous system include acute disseminated encephalomyelitis, neuromyelitis optica spectrum disorder, multiple sclerosis and transverse myelitis. (a) Mean serum a-synuclein levels showed significant differences in patients with epilepsy and acquired demyelinating disorders of the CNS compared to controls ( $p=$ 0.0103). (b) Serum a-synuclein levels showed a significant positive correlation with the number of antiepileptic drugs used by epilepsy patients ( $p=0.0222, r=0.2132$ ). (c) Serum a-synuclein levels showed a significant positive correlation with the duration of disease in patients with acute demyelinating disorders of the CNS ( $p=0.0374, r=0.5892)$. (d) Mean exosomal a-synuclein levels were not significantly different in patients with epilepsy or acquired demyelinating disorders of the central nervous system compared to controls $(p=0.2341)$. (e-f) Correlation of exosome asynuclein levels with serum a-synuclein levels (e) and with serum IL-6 levels (f) in combined groups of patients with epilepsy ( $\mathrm{N}=115)$ plus patients with acquired demyelinating disorders of the CNS $(\mathrm{N}=18)$ and controls $(\mathrm{N}=146)$. (e) Exosome a-synuclein levels showed a significant

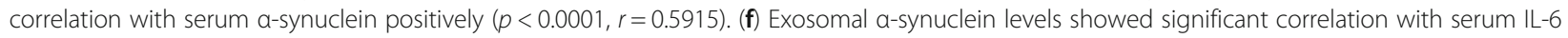
levels positively ( $p=0.0334, r=0.1349)$. Ds, disorders; No, numbers; AED, antiepileptic drugs; CNS, central nervous system; IL, interleukin 
0.0001, $r=0.5915)$. Additionally, exosomal $\alpha$-synuclein showed correlation with serum IL-6 levels in patients with epilepsy and acquired demyelinating disorders of the CNS (Fig. 1 (E), $p<0.05, r=0.1349$ ). However, exosomal $\alpha$ synuclein levels did not show a significant correlation with the measures of disease severity, such as number of antiepileptic medication and duration of disease, both in patients with epilepsy and with acquired demyelinating diseases of the CNS (Table 5).

\section{Serum cytokine profiles and correlation with the measures of disease severity}

Negative correlation of serum levels of IFN-r, IL-1 $\beta$, IL-6 and IL-10 with the age of disease onset in pediatric epilepsy patients with seizure attack within $48 \mathrm{~h}$ Serum levels of proinflammatory cytokines, IL-6 and TNF- $\alpha$ were significantly increased in pediatric epilepsy patients with acute afebrile seizure attacks within $48 \mathrm{~h}$ compared to controls (Tables $4,4.2 \mathrm{vs} 0.9 \mathrm{pg} / \mathrm{ml}$ for IL-6, $p<0.05$; 14.3 vs $10.2 \mathrm{pg} / \mathrm{ml}$ for TNF- $\alpha, p<0.05)$. The anti-inflammatory cytokine IL-10 was also significantly increased compared to the controls (Tables 4, 9.2 vs $4.0 \mathrm{pg} / \mathrm{ml}, p<0.0001)$. Serum levels of IFN- $\beta$, IFN- $\gamma$ and IL-1 $\beta$ were higher compared to controls, although the differences were not statistically significant (Tables
$4,475.5$ vs 397.5 for IFN- $\beta, p=0.0646 ; 4.6$ vs 3.5 for IFN- $\gamma, p=0.178 ; 3.5$ vs $0.5 \mathrm{pg} / \mathrm{ml}$ for IL- $1 \beta, p=0.1038)$.

Correlation analysis between serum cytokine levels and disease severity revealed that age at disease onset showed significant correlation negatively with serum levels of IFN-r, IL-1 $\beta$, IL- 6 and IL-10, indicating that the younger the patients were at disease onset, the more higher their cytokine levels to acute symptom of seizures (Table 5 and Fig. 2 (A-D), $p<0.0001, r=-0.4197$ for IFN- $\gamma, p=00110, \mathrm{r}=-0.2545$ for IL-1 $\beta ; p=0.0066, \mathrm{r}=-$ 0.2714 for IL-6; $p=0.0041, \mathrm{r}=-0.2864$ for IL-10).

Positive correlation of serum levels of IL-1 $\beta$ and IFN$\gamma$ with numbers of antiepileptic medication and IL-6 with duration of last seizure before the blood collection in pediatric epilepsy patients with seizure attack within $48 \mathrm{~h}$ The numbers of antiepileptic drug showed significant correlation with serum levels of IL-1 $\beta$ and IFN- $\gamma$, positively (Table 5; Fig. 3 (A), $p<0.001, r=$ 0.3428 for IL-1 $\beta$; Fig. 3 (B), $p<0.05, r=0.2288$ for IFN$\gamma)$. Disease durations in patients with epilepsy showed no significant correlation with serum levels of cytokines (Table 5). The duration of last seizure before the blood collection showed significant correlation with serum levels of IL-6, positively (Table 5; Fig. 3 (D), $p<0.05, \mathrm{r}=$ 0.2773).

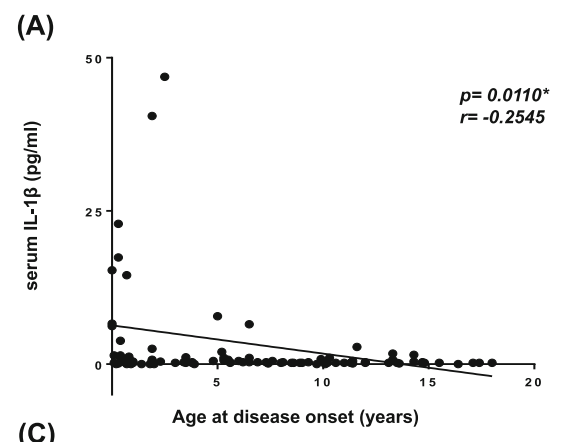

(B)
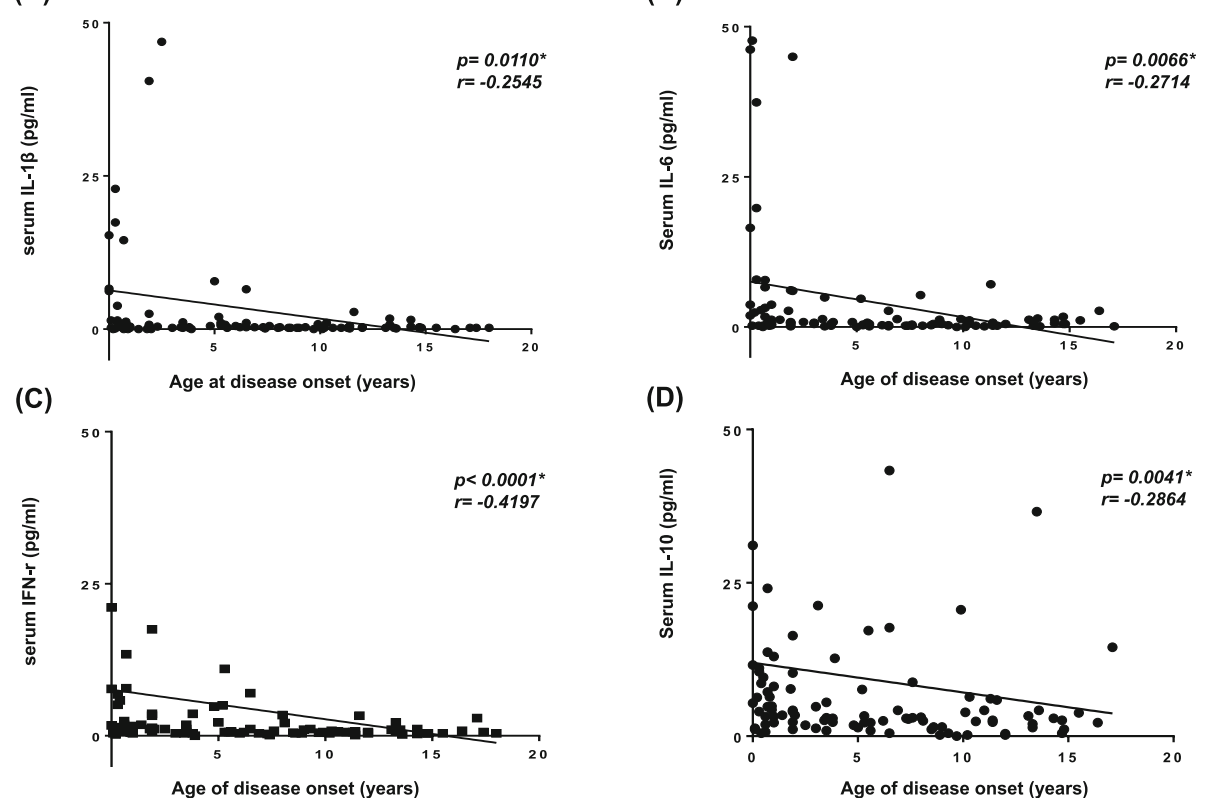

(D)

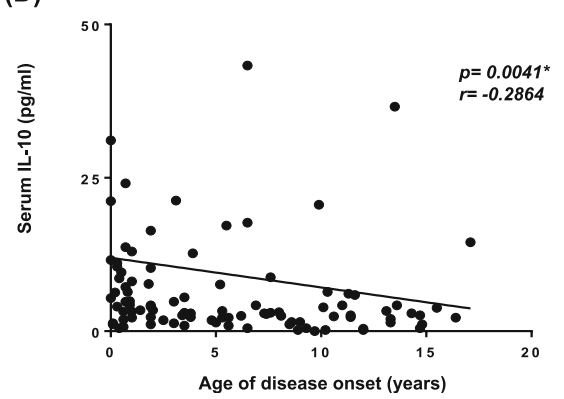

Fig. 2 Correlation of serum levels of cytokines with age of disease onset in patients with epilepsy. (a-d) Correlation of serum levels of IL-1 $\beta$ (a), IL6 (b), IFN- $\gamma(\mathbf{c})$ and IL-10 (d) with age of disease onset in patients with epilepsy $(\mathrm{N}=115)$. (a) Serum levels of IL-1 $\beta$ showed a significant negative correlation with age of disease onset in children with epilepsy ( $p=0.0110, r=-0.2545)$. (b) Serum levels of IL-6 showed a significant negative correlation with age of disease onset in children with epilepsy ( $p=0.0066, r=-0.2714)$. (c) Serum levels of IFN- $\gamma$ showed a significant negative correlation with age of disease onset in children with epilepsy $(p<0.0001, r=-0.4197)$. (d) Serum levels of IL-10 showed a significant negative correlation with age of disease onset in children with epilepsy $(p=0.0041, r=-0.2864)$. IL, interleukin; IFN, interferon 
(A)

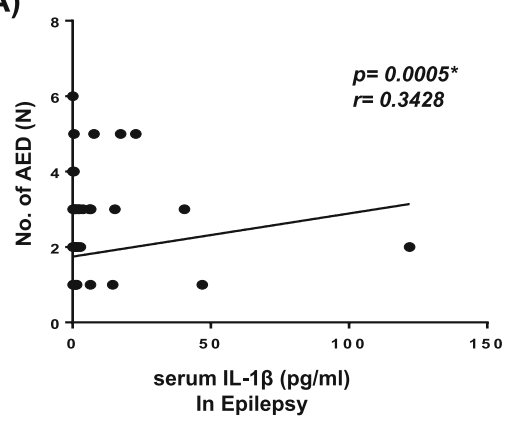

(C)

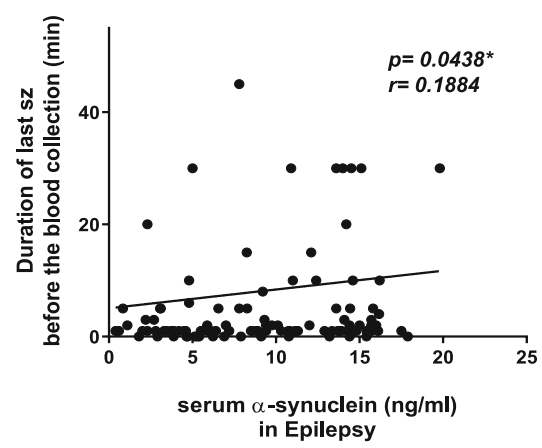

(B)

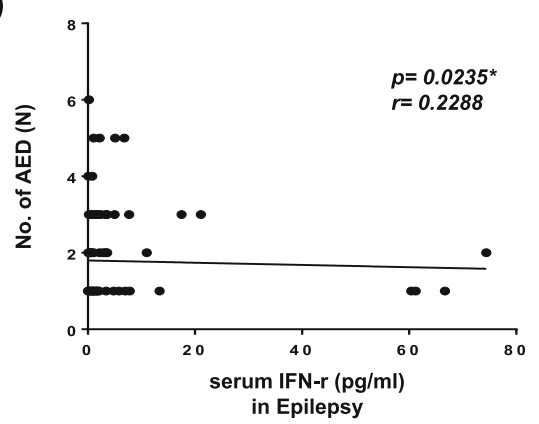

(D)

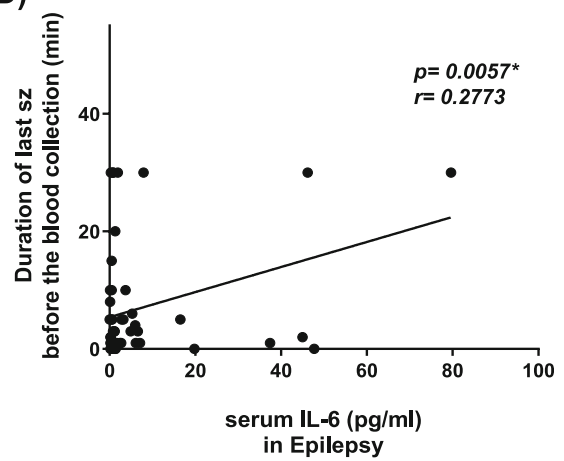

Fig. 3 Correlation of serum a-synuclein with measures of the disease severity in epilepsy and acquired demyelinating disorders of CNS. (a-b) Correlation between the numbers of antiepileptic drug and serum levels of IL-1 $\beta$ (a) and IFN- $\gamma$ (b). (a) Serum IL-1 $\beta$ levels showed a significant positive correlation with the numbers of antiepileptic drug taken for control of seizures in children with epilepsy $(p=0.0005, r=0.3428)$. (b) Serum IFN-r levels showed a significant positive correlation with the numbers of antiepileptic drug for control of seizures in children with epilepsy $(p=0.0235, r=0.2288)$ (c-d) Correlation between the duration of last seizure before the blood collection and serum levels of a-synuclein (c) and IL-6 (d). (a) Serum a-synuclein levels showed a significant positive correlation with the duration of last seizure before the blood collection in children with epilepsy $(p=0.0438, r=0.1884)$. (b) Serum IL-6 levels showed a significant positive correlation with the duration of last seizure before the blood collection in children with epilepsy $(p=0.0057, r=0.2773)$. CNS, central nervous system; No, numbers; AED, numbers of antiepileptic drug; IL, interleukin; IFN, interferon; sz, seizure.

Increased serum IL-10 levels and negative correlation of serum IL-6 levels with age of disease onset in patients with acquired demyelinating disorders of the CNS The serum IL-10 level was significantly increased in patients with acquired demyelinating disorders of the CNS compared to controls (Tables $4,17.7$ vs $4.0 \mathrm{pg} / \mathrm{ml}$, $p<0.05)$. Serum levels of IFN- $\beta$, IFN- $\gamma$, and IL-6 were increased compared to controls, although the difference was not statistically significant (Tables $4,814.9$ vs 397.5 for IFN- $\beta, 6.1$ vs 3.5 for IFN-r, 7.0 vs 0.9 for IL-6). Other proinflammatory cytokines, including IL- $1 \beta$ and TNF- $\alpha$, did not differ from the controls (Table 4).

Correlation analysis between serum cytokine levels and disease severity revealed that the age of disease onset was significantly correlated with serum levels of IL-6, which indicates that the younger the more aggravated cytokine responses to acute symptoms or relapse (Table $5, p=0.0429, \mathrm{r}=-0.6272)$. The disease durations did not show significant correlation with serum levels of cytokines in patients with acquired demyelinating disorders of the CNS (Table 5).

\section{Discussion}

This is the first study demonstrating that serum $\alpha$ synuclein levels were significantly increased in children with epilepsy and acquired demyelinating disorders of the CNS and correlated with the measures of disease severity, suggesting neurodegenerative process. Exosome $\alpha$-synuclein levels, probably CNS-derived, are correlated with serum levels of $\alpha$-synuclein and IL-6. Serum levels of the proinflammatory cytokine IL- $1 \beta$ showed significant correlation with the measures of disease severity only in children with epilepsy but not in acquired demyelinating disorders in the CNS, implicating IL- $1 \beta$ as a potential prognostic biomarker for childhood epilepsy as ongoing neuroinflammation. Serum levels of IFN- $\gamma$, IL$1 \beta$, IL- 6 and IL-10 showed negative correlation with age of disease onset in pediatric epilepsy patients, suggesting that younger patients demonstrated higher inflammatory responses to afebrile seizure attacks. Thus, these data suggest that serum levels of IL-1 $\beta$ are potential prognostic biomarker specific for children with epilepsy and serum levels of $\alpha$-synuclein are a potential prognostic 
biomarker for both drug resistant epilepsy and acquired demyelinating disorders of the CNS in children.

Many molecules and pathways are activated after acute brain injuries, such as cerebrovascular damage, infections, seizures and traumatic brain injury, often leading to the development of chronic neuroinflammation not only in typical neuroinflammatory disorders such as multiple sclerosis and acute disseminated encephalomyelitis but also in epilepsies [19, 30,31]. Childhood is the most common period for a variety of infections. Interestingly, the proinflammatory cytokines IFN- $\gamma, \mathrm{IL}-1 \beta$ and IL-6 were negatively correlated with the age of disease onset in children with epilepsy, suggesting that younger patients demonstrated a more aggravated inflammatory response to recent seizure attacks. This childhood tendency toward hyper-responsiveness to acute seizure attacks may aggravate the proinflammatory response to diverse insults, such as infection, trauma and even febrile seizures, and may cause sustained neuroinflammation leading to epilepsy.

IL-1 $\beta$ is one of the most important proinflammatory cytokines produced in the CNS by activated microglia and astrocytes, as well as by macrophages and other immune cells in the periphery. IL-1 $\beta$ upregulates excitatory glutamatergic neurotransmission and lowers inhibitory gamma-aminobutyric acid (GABA)-mediated currents [32]. In experimental animals, IL-1 $\beta$ injection prolongs the duration of electroencephalographic seizure [33]. Epileptogenesis is a continuing process that begins before the first seizure and continues after epilepsy diagnosis. Considerable effort has been devoted to the search for biomarkers of epilepsy or ongoing epileptogenesis, including blood, brain imaging, electrophysiology and pathology $[34,35]$. In traumatic brain injury, CSF/serum levels of IL-1 $\beta$ and IL-1 $\beta$ genetic variants were reported as prognostic factors for posttraumatic epilepsy risk in humans [21]. In our study, serum IL-1 $\beta$ levels within 48 $\mathrm{h}$ after afebrile seizure attacks showed correlation with the numbers of antiepileptic drugs being used by children with epilepsy. An increase in the number of antiepileptic drugs suggests drug resistance in patients, so the increase in serum IL-1 $\beta$ may correlate with drug resistance or with ongoing epileptogenesis or neuroinflammation. Interestingly, serum IL- $1 \beta$ did not correlate with the measure of disease severity in children with acquired demyelinating disorders of the CNS, the prototype of autoimmune neuroinflammation. Thus, serum IL-1 $\beta$ may be specific to neuroinflammation for epilepsy development, implicating it as a prognostic biomarker for epilepsy.

Expression of $\alpha$-synuclein is increased during epileptogenesis [23, 36]. Status epilepticus triggers an increase of $\alpha$-synuclein expression in the dentate gyrus of animal models with pilocarpine-induced epilepsy [23] and in the hippocampus of patients with mesial temporal lobe epilepsy [36]. In our study, serum $\alpha$-synuclein was significantly increased in children with epilepsy and with acquired demyelinating disorders of the CNS, the prototype of autoimmune neuroinflammatory disorders of the CNS in childhood. Moreover, serum $\alpha$-synuclein levels were positively correlated with measures of disease severity for both epilepsy and acquired disorders of the CNS, implying that serum $\alpha$-synuclein is a potential prognostic biomarker of neurodegenerative processes. Serum levels of $\alpha$-synuclein were also correlated with exosome $\alpha$-synuclein levels, the presumptive fraction from the CSF. Moreover, exosomal $\alpha$-synuclein levels showed significant correlation with serum IL-6 levels in children with epilepsy and acquired demyelinating disorders of the CNS. And the longer the duration of seizure, the higher serum IL-6 levels was in our children with epilepsy. In human astrocyte cell lines, $\alpha$-synuclein can directly stimulate astrocyte production of IL-6 [37]. Astrocytes are a major source of proinflammatory cytokines, such as IL-1 $\beta$ and IL-6, even causing neurotoxicity. Therefore, correlation between the serum IL-6 levels and exosomal $\alpha$-synuclein supports the viscous neurotoxicity cycle of neuroinflammation in epilepsy patients. Although exosome $\alpha$-synuclein levels did not show a significant correlation with the measure of disease severity in patients with epilepsy and with acquired demyelinating disorders of the CNS in our study, probably due to the small number of patients available exosome fraction of serum. The sensitivity of the method used to extract exosomes from the peripheral blood could be problematic, and these commercially available methods are not free from protein contamination and may affect the properties of the exosomes [38].

In recent studies of children with autism spectrum disorder [39] and with attention-deficit/hyperactivity disorder, serum $\alpha$-synuclein levels are reported to be low or no changes compared to controls [40]. Therefore serum $\alpha$-synuclein levels may suggest neurodegenerative process related with neuroinflammation in children.

Our study has some limitations. First, a relatively small number of patients were enrolled, especially children with acquired demyelinating disorders of the CNS, as positive controls. Second, $\alpha$-synuclein exists in several different forms, such as oligomeric, phosphorylated and total forms; however, we measured only the total form. Third, exosome $\alpha$-synuclein should be measured by a more accurate method to increase sensitivity. Fourth, to distinguish neuroinflammation or neurodegeneration, such as neurocognitive dysfunction, neurocognitive tests for children with epilepsy at the time of initial and follow-ups must be conducted and compared with serum levels of $\alpha$-synuclein and IL- $1 \beta$. 


\section{Conclusions}

In summary, we demonstrated that serum levels of $\alpha$ synuclein were significantly increased both in children with epilepsy and with acquired demyelinating disorders of the CNS and that serum $\alpha$-synuclein was correlated with measures of disease severity. Serum levels of IL-1 $\beta$ showed a significant correlation with measures of disease severity only in children with epilepsy but not in those with acute demyelinating disorders of the CNS. Thus, these data support that serum $\alpha$-synuclein are potential prognostic biomarkers for disease severity in children with epilepsy and acquired demyelinating disorders of the CNS and serum IL- $1 \beta$ is a specific biomarker for drug-resistance in children with epilepsy. However, further studies including larger sample sizes and neurocognitive testing are needed to confirm the usefulness of serum $\alpha$-synuclein and IL- $1 \beta$ as prognostic biomarkers for epilepsy.

\begin{abstract}
Abbreviations
ADEM: acute disseminated encephalomyelitis; CNS: central nervous system: CSF: Cerebrospinal fluid; EEG: electroencephalogram; ELISA: enzyme-linked immunosorbent assay; GABA: gamma-aminobutyric acid; ICAM: Intercellular Adhesion Molecule; IFN: interferon; IL: interleukin; ILAE: International League Against Epilepsy; MRI: magnetic resonance imaging; NMOSD: neuromyelitis optica spectrum disorder; SD: standard deviation; TM: transverse myelitis; TNF: tumor necrosis factor
\end{abstract}

\section{Acknowledgements}

Not applicable.

\section{Author's contributions}

JC1 and JS conceived of the study and designed the experiments. SK, HK, BL, $\mathrm{HH}, \mathrm{JC} 2$ and KK treated the patients and interpreted the patient data. JC1 and JS and wrote the manuscript. EK and JC1 performed the experiments. $\mathrm{SO}$ and JS analyzed the data. All authors read and approved final manuscript.

\section{Funding}

The analysis of cytokines was supported by the Basic Science Research Program through the National Research Foundation of Korea (NRF) funded by the Ministry of Education (No. 2016R1A2B4009438), the Seoul National University Hospital Research Fund (No. 03-2015-0120), and the analysis of asynuclein and exosomal analysis were supported by the Seoul National University Boramae Hospital Research Fund (No. 03-2013-8 and 01-2014-11) to JC1. The correlation analysis of cytokines and a-synuclein were supported by grants from the NRF funded by the Korean government (MEST) (No. 2017R1A2B3006704 and 2019R1A6A1A03032869) to JS. The role of the funding bodies is data collection, data analysis and document retrieval.

\section{Availability of data and materials}

The datasets used and/or analyzed during the current study are available from the corresponding author on reasonable request.

\section{Ethics approval and consent to participate}

All relevant study documentation was reviewed and approved by the responsible Institutional Review Board at the Seoul National University Boramae Medical Center (20080918/06-2008-74/76). Informed written consent was obtained from the parent of each child, and verbal assent was obtained from each child or adolescent.

\section{Consent for publication}

Not applicable.

\section{Competing interests}

The authors declare no potential conflicts of interest with respect to the research, authorship, and/or publication of this article.

\section{Author details}

${ }^{1}$ Department of Pediatrics, Seoul National University College of Medicine Seoul Metropolitan Government Seoul National University Boramae Medical Center, Boramaero 5 gil 20, Dongjakgu, Seoul 07061, South Korea.

${ }^{2}$ Department of Pediatrics, Pediatric Clinical Neuroscience Center, Seoul National University Children's Hospital, Seoul National University College of Medicine, Seoul, South Korea. ${ }^{3}$ Department of Pediatrics, Seoul National University Bundang Hospital, Seoul, South Korea. ${ }^{4}$ Department of Biostatistics, SMG-SNU Boramae Medical Center, Seoul National University College of Medicine, Seoul, South Korea. ${ }^{5}$ Department of Microbiology, Brain Korea 21 Plus Project for Medical Science, Severance Biomedical Science Institute and Institute for Immunology and Immunological Diseases, Yonsei University College of Medicine, 50-1 Yonsei-ro Seodaemoon-gu Seoul, Seoul 03722, South Korea.

Received: 15 July 2019 Accepted: 27 February 2020

Published online: 09 March 2020

\section{References}

1. Thurman DJ, Beghi E, Begley CE, Berg AT, Buchhalter JR, Ding D, et al. Standards for epidemiologic studies and surveillance of epilepsy. Epilepsia. 2011;52(Suppl 7):2-26.

2. Kwan P, Arzimanoglou A, Berg AT, Brodie MJ, Allen Hauser W, Mathern G, et al. Definition of drug resistant epilepsy: consensus proposal by the ad hoc task force of the ILAE commission on therapeutic strategies. Epilepsia. 2010;51(6):1069-77.

3. Camfield P, Camfield C. Regression in children with epilepsy. Neurosci Biobehav Rev. 2019;96:210-8.

4. Camacho A, Espin JC, Nunez N, Simon R. Levetiracetam-induced reversible autistic regression. Pediatr Neurol. 2012;47(1):65-7.

5. Berg AT, Smith SN, Frobish D, Beckerman B, Levy SR, Testa FM, et al. Longitudinal assessment of adaptive behavior in infants and young children with newly diagnosed epilepsy: influences of etiology, syndrome, and seizure control. Pediatrics. 2004;114(3):645-50.

6. Nakai M, Fujita M, Waragai M, Sugama S, Wei J, Akatsu H, et al. Expression of alpha-synuclein, a presynaptic protein implicated in Parkinson's disease, in erythropoietic lineage. Biochem Biophys Res Commun. 2007;358(1):104-10.

7. Barbour R, Kling K, Anderson JP, Banducci K, Cole T, Diep L, et al. Red blood cells are the major source of alpha-synuclein in blood. Neurodegener Dis. 2008;5(2):55-9.

8. Iwai A, Masliah E, Yoshimoto M, Ge N, Flanagan L, de Silva HA, et al. The precursor protein of non-a beta component of Alzheimer's disease amyloid is a presynaptic protein of the central nervous system. Neuron. 1995;14(2): 467-75.

9. Murphy DD, Rueter SM, Trojanowski JQ, Lee VM. Synucleins are developmentally expressed, and alpha-synuclein regulates the size of the presynaptic vesicular pool in primary hippocampal neurons. J Neurosci. 2000;20(9):3214-20.

10. Adamczyk A, Strosznajder JB. Alpha-synuclein potentiates Ca2+ influx through voltage-dependent Ca2+ channels. Neuroreport. 2006;17(18):18836.

11. Martin ZS, Neugebauer V, Dineley KT, Kayed R, Zhang W, Reese LC, et al. Alpha-Synuclein oligomers oppose long-term potentiation and impair memory through a calcineurin-dependent mechanism: relevance to human synucleopathic diseases. J Neurochem. 2012;120(3):440-52.

12. Barker RA, Williams-Gray CH. Review: the spectrum of clinical features seen with alpha synuclein pathology. Neuropathol Appl Neurobiol. 2016;42(1):6-19.

13. El-Agnaf OM, Salem SA, Paleologou KE, Curran MD, Gibson MJ, Court JA, et al. Detection of oligomeric forms of alpha-synuclein protein in human plasma as a potential biomarker for Parkinson's disease. FASEB J. 2006;20(3): 419-25.

14. Shi M, Liu C, Cook TJ, Bullock KM, Zhao Y, Ginghina C, et al. Plasma exosomal alpha-synuclein is likely CNS-derived and increased in Parkinson's disease. Acta Neuropathol. 2014;128(5):639-50.

15. Wang H, Wang K, Xu W, Wang C, Qiu W, Zhong X, et al. Cerebrospinal fluid alpha-synuclein levels are elevated in multiple sclerosis and neuromyelitis optica patients during replase. J Neurochem. 2012;122(1):19-23.

16. Su E, Bell MJ, Wisniewski SR, Adelson PD, Janesko-Feldman KL, Salonia R, et al. Alpha-Synuclein levels are elevated in cerebrospinal fluid following traumatic brain injury in infants and children: the effect of therapeutic hypothermia. Dev Neurosci. 2010;32(5-6):385-95. 
17. Lassmann $\mathrm{H}$. Axonal and neuronal pathology in multiple sclerosis: what have we learnt from animal models. Exp Neurol. 2010;225(1):2-8.

18. Choi J, Koh S. Role of brain inflammation in epileptogenesis. Yonsei Med J. 2008:49(1):1-18

19. Vezzani A, French J, Bartfai T, Baram TZ. The role of inflammation in epilepsy. Nat Rev Neurol. 2011;7(1):31-40.

20. Pitkanen A, Loscher W, Vezzani A, Becker AJ, Simonato M, Lukasiuk K, et al. Advances in the development of biomarkers for epilepsy. Lancet Neurol. 2016;15(8):843-56.

21. Diamond ML, Ritter AC, Failla MD, Boles JA, Conley YP, Kochanek PM, et al, IL-1 beta associations with posttraumatic epilepsy development: a genetics and biomarker cohort study. Epilepsia. 2014;55(7):1109-19.

22. Pollard JR, Eidelman O, Mueller GP, Dalgard $\mathrm{CL}$, Crino PB, Anderson $C T$, et al. The TARC/sICAM5 ratio in patient plasma is a candidate biomarker for drug resistant epilepsy. Front Neurol. 2012;3:181.

23. Li A, Choi YS, Dziema H, Cao R, Cho HY, Jung YJ, et al. Proteomic profiling of the epileptic dentate gyrus. Brain Pathol. 2010;20(6):1077-89.

24. Rong $\mathrm{H}$, Jin L, Wei W, Wang X, Xi Z. Alpha-synuclein is a potential biomarker in the serum and CSF of patients with intractable epilepsy. Seizure. 2015;27: 6-9.

25. Scheffer IE, Berkovic S, Capovilla G, Connolly MB, French J, Guilhoto L, et al. ILAE classification of the epilepsies: position paper of the ILAE Commission for Classification and Terminology. Epilepsia. 2017;58(4):512-21.

26. Krupp LB, Tardieu M, Amato MP, Banwell B, Chitnis T, Dale RC, et al. International pediatric multiple sclerosis study group criteria for pediatric multiple sclerosis and immune-mediated central nervous system demyelinating disorders: revisions to the 2007 definitions. Mult Scler. 2013; 19(10):1261-7

27. Polman CH, Reingold SC, Banwell B, Clanet M, Cohen JA, Filippi M, et al. Diagnostic criteria for multiple sclerosis: 2010 revisions to the McDonald criteria. Ann Neurol. 2011;69(2):292-302.

28. Wingerchuk DM, Banwell B, Bennett JL, Cabre P, Carroll W, Chitnis T, et al. International consensus diagnostic criteria for neuromyelitis optica spectrum disorders. Neurology. 2015;85(2):177-89.

29. Zhou J, Chen L, Chen B, Huang S, Zeng C, Wu H, et al. Increased serum exosomal miR-134 expression in the acute ischemic stroke patients. BMC Neurol. 2018;18(1):198.

30. Choi J, Min HJ, Shin JS. Increased levels of HMGB1 and pro-inflammatory cytokines in children with febrile seizures. J Neuroinflammation. 2011;8:135.

31. Choi J, Nordli DR Jr, Alden TD, DiPatri A Jr, Laux L, Kelley K, et al. Cellular injury and neuroinflammation in children with chronic intractable epilepsy. J Neuroinflammation. 2009:6:38.

32. Dube C, Vezzani A, Behrens M, Bartfai T, Baram TZ. Interleukin-1 beta contributes to the generation of experimental febrile seizures. Ann Neurol. 2005;57(1):152-5.

33. Vezzani A, Conti M, De Luigi A, Ravizza T, Moneta D, Marchesi F, et al. Interleukin-1 beta immunoreactivity and microglia are enhanced in the rat hippocampus by focal kainate application: functional evidence for enhancement of electrographic seizures. J Neurosci. 1999;19(12):5054-65.

34. Terrone G, Salamone A, Vezzani A. Inflammation and epilepsy: preclinical findings and potential clinical translation. Curr Pharm Des. 2017;23(37):5569-76.

35. Pitkanen A, Ekolle Ndode-Ekane X, Lapinlampi N, Puhakka N. Epilepsy biomarkers - toward etiology and pathology specificity. Neurobiol Dis. 2019; 123:42-58.

36. Yang JW, Czech T, Felizardo M, Baumgartner C, Lubec G. Aberrant expression of cytoskeleton proteins in hippocampus from patients with mesial temporal lobe epilepsy. Amino Acids. 2006;30(4):477-93.

37. Klegeris A, Giasson BI, Zhang H, Maguire J, Pelech S, McGeer PL. Alphasynuclein and its disease-causing mutants induce ICAM-1 and IL-6 in human astrocytes and astrocytoma cells. FASEB J. 2006;20(12):2000-8.

38. Wang L, Bruce TF, Huang S, Marcus RK. Isolation and quantitation of exosomes isolated from human plasma via hydrophobic interaction chromatography using a polyester, capillary-channeled polymer fiber phase. Anal Chim Acta. 2019;1082:186-93.

39. Sriwimol W, Limprasert P. Significant changes in plasma alpha-Synuclein and Beta-Synuclein levels in male children with autism Spectrum disorder. Biomed Res Int. 2018;2018:4503871.

40. Cetin I, Simsek S. A preliminary study on investigation of serum alphaSynuclein and tau protein levels in children with attention deficit hyperactivity disorder. Indian J Clin Biochem. 2017;32(3):285-91.

\section{Publisher's Note}

Springer Nature remains neutral with regard to jurisdictional claims in published maps and institutional affiliations.
Ready to submit your research? Choose BMC and benefit from:

- fast, convenient online submission

- thorough peer review by experienced researchers in your field

- rapid publication on acceptance

- support for research data, including large and complex data types

- gold Open Access which fosters wider collaboration and increased citations

- maximum visibility for your research: over $100 \mathrm{M}$ website views per year

At $\mathrm{BMC}$, research is always in progress.

Learn more biomedcentral.com/submissions 